\title{
Examination Management Systems: A Survey of User Acceptance Level in UiTM Cawangan Pulau Pinang
}

\author{
Jamal Othman ${ }^{1 *}$, Rozita Kadar ${ }^{2}$, Naemah Abdul Wahab ${ }^{3}$, Saiful Nizam Warris ${ }^{4}$ \\ ${ }_{1,2,3,4}$ Department of Computer and Mathematical Sciences, Universiti Teknologi MARA Cawangan Pulau Pinang, \\ Malaysia
}

Corresponding author:*jamalothman@ppinang.uitm.edu.my

Received Date: 2 April 2018

Accepted Date: 4 October 2018

\begin{abstract}
Examination Management Systems (EMS) is a comprehensive system developed using JAVA programming language for data processing and Microsoft Access for reporting purposes. This system has been used and implemented at several campuses including Universiti Teknologi MARA Cawangan Pulau Pinang, Permatang Pauh Campus. The core objective of this system is to improve the efficiency and reducing the operational risks. A survey has been conducted to examine the user acceptance level of UiTM Cawangan Pulau Pinang since implemented in 2014. Questionnaires have been distributed to chief invigilators at every session of examination for 10 semesters and results of analysis are reported and concluded.
\end{abstract}

Keywords: Examination Management Systems (EMS), Examination Placement, Invigilators, DBMS

\section{INTRODUCTION}

Examination operations are the main crucial task in any education institutions. In the Quality Manual Report of UiTM Cawangan Pulau Pinang, ISO 9001:2008 (Quality, 2008) and Examination Procedures Manual 2016 (UiTM, 2016), the operations of examination are considered as serious matter either at the phase of preparation of examination question papers, handling of printing and packaging of question papers, marks management operation or invigilation managements. The problem of question paper leakages is the highest credibility of an education institution if there is no proper division to control the secrecy and integrity of the examination operations. Academic Assessment Division at the main campus was created to manage the operations of examination in all campuses and faculties. Each faculties and campuses formed an examination unit to make sure that the operations are running according to the rules and procedures as stated in the Examination Procedures Manual. As cited in a paper by Xu, Guo, \& Zhou (2013), they have stated that Lai (2012) has mentioned examination as an effective indicator to measure and assess the students' quality and their ability to foster critical answers. The quality is refers to the preparation of question papers, the secrecy and security aspects in printing and packaging of question papers, the integrity of evaluation and marking methods and the standardization of examination operations. Failures to enforce and sustain the quality, procedures and policies of examination will give some negative impacts and perceptions on examination management.

Examination process involves several entities such as academic affairs for enrolments, facilities for preparation of examination venues, bursary for payment status of students' university fees and printing department for printing and packaging of question papers. Examination Management Systems (EMS) has been developed to integrate all management levels and consolidate all important processes using the same platform. Formerly, the staffs at Examination Unit had to face complicated process such as manual calculation of total enrolment for each paper, manual placement of examination venues and manual 
assignment of invigilators list. EMS helps to automate the previous manual tasks and these reduced the stressful in data processing.

\section{EXAMINATION MANAGEMENT SYSTEMS (EMS)}

This section discusses the development of EMS that described about the procedures taken since the beginning until the end of system development. In the first subsection, the methodology conducted in this study is discussed based on the Prototyping Software Development Methodology model. Next, the procedures taken in developing prototype are discussed in detail. The Incremental Prototyping approach is applied in developing the prototype which consists of four main processes, which are examination placement, examination seating number, printing and packaging of question paper; and assignment of invigilators.

\section{Methodology}

The system has been developed based on the Prototyping Software Development Methodology model. The stepwise involves the identification of basic requirements, develop the initial prototype, review, revise, enhance the prototype, and these continues and repeated until all requirements of the system are fulfilled. The Incremental Prototyping approach is applied in the software development because the system consists of multiple modules or functionality of various sub-systems and integrates all prototypes to form a complete system (Griesel, 1988).

\section{The Development of Examination Management Systems (EMS)}

Examination Management Systems (EMS) historically developed in 2006 after the developer found the constraints and problems faced by the supporting staffs and examination members committee amongst lecturers during the preparation of examination placement venue and assigning of invigilators. Both processes took 3 consecutive weeks to be completed. In some cases, the lecturers have to sacrifice some of their classes such as class cancellation, unpunctuality and extended the class over midnight to precede with the examination affairs. These become so stressful to all staffs whenever the examination season arises. As mentioned by Zhang, Liu, \& Zang (2014), efficient and standardize examination management systems is the important element to ensure that the examination runs smoothly. With this point, the examination members committee should have positive enthusiastic and highly motivated to arrange the best examination placement and assigning appropriate invigilators to meet the objective of Examination Unit. Otherwise, the Examination Unit will be blamed because of the failure to give better services or satisfaction amongst students or invigilators.

EMS makes sure the process of major processes such as placement of examination venues and invigilation will be taken within 4 to 6 days. Previously it took almost 3 weeks to complete both processes. Formerly almost 10 staffs are needed to complete the tasks, but EMS only require not more than 5 peoples which comprises of an Executive Officer, 2 representatives of examination members committee and 2 technical persons.

Vasupongayya, Noodam, \& Kongyong (2013) has dictate the major modules of any Examination Management Systems are to arrange the examination rooms for each course and assignment of proctors or invigilators in each room. EMS at UiTM Cawangan Pulau Pinang not only covers the arrangement of examination rooms and invigilation, but it also organized the printing and packaging of the question papers, examination operations and generating seating numbers arrangement in each room. These 5 modules are the main functions of EMS which each module are integrated with every single entities such as students, admin staffs, invigilators or examination committee member levels. 
EMS requires data from multiple sources such as the enrolments records, examination schedules, examination venues, list of invigilators and list of constraints. The examination schedules are assigned by the Academic Assessment Division. The students' enrolments are downloaded from Academic Affairs Division through Student Information Management Systems (SIMS). The other data such as the examination venues, list of invigilators and respective constraints are provided by the Executive Officer at faculties or campuses level. The following figure shows the overall procedures and flows of EMS.

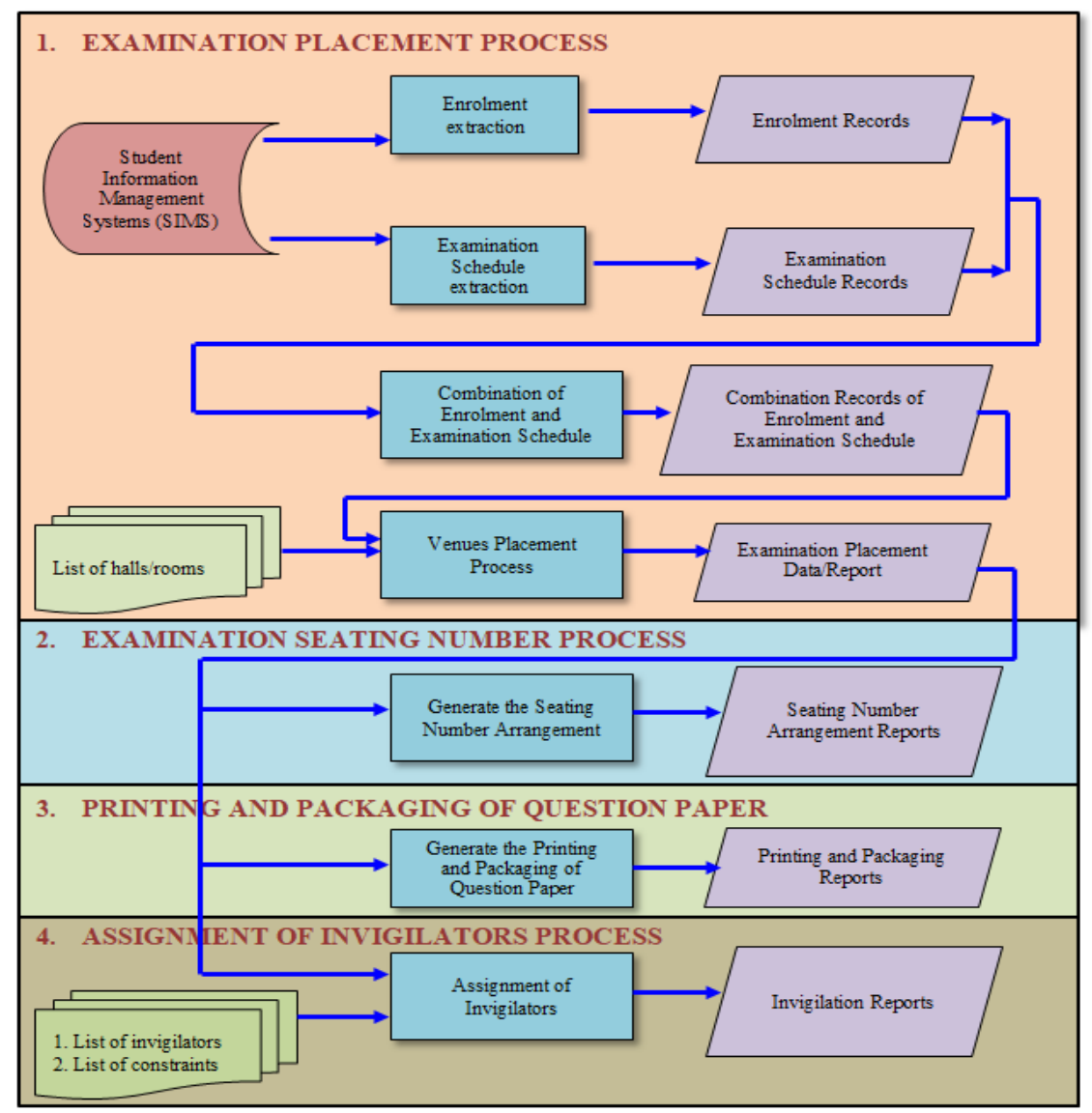

Figure 1: Details flow of Examination Management Systems (EMS)

Assignment of invigilators or proctors will be the final task of EMS. EMS pumps all records which have been processed into text file formatting before generating all required reports using Microsoft Access Database Management Systems (DBMS). Executive Officer of Examination Unit will generate each report individually as PDF file and will send those reports to the photocopier machine or invigilation reports will be emailed to the invigilators. The following figure illustrates samples of reports generated by EMS Database. 


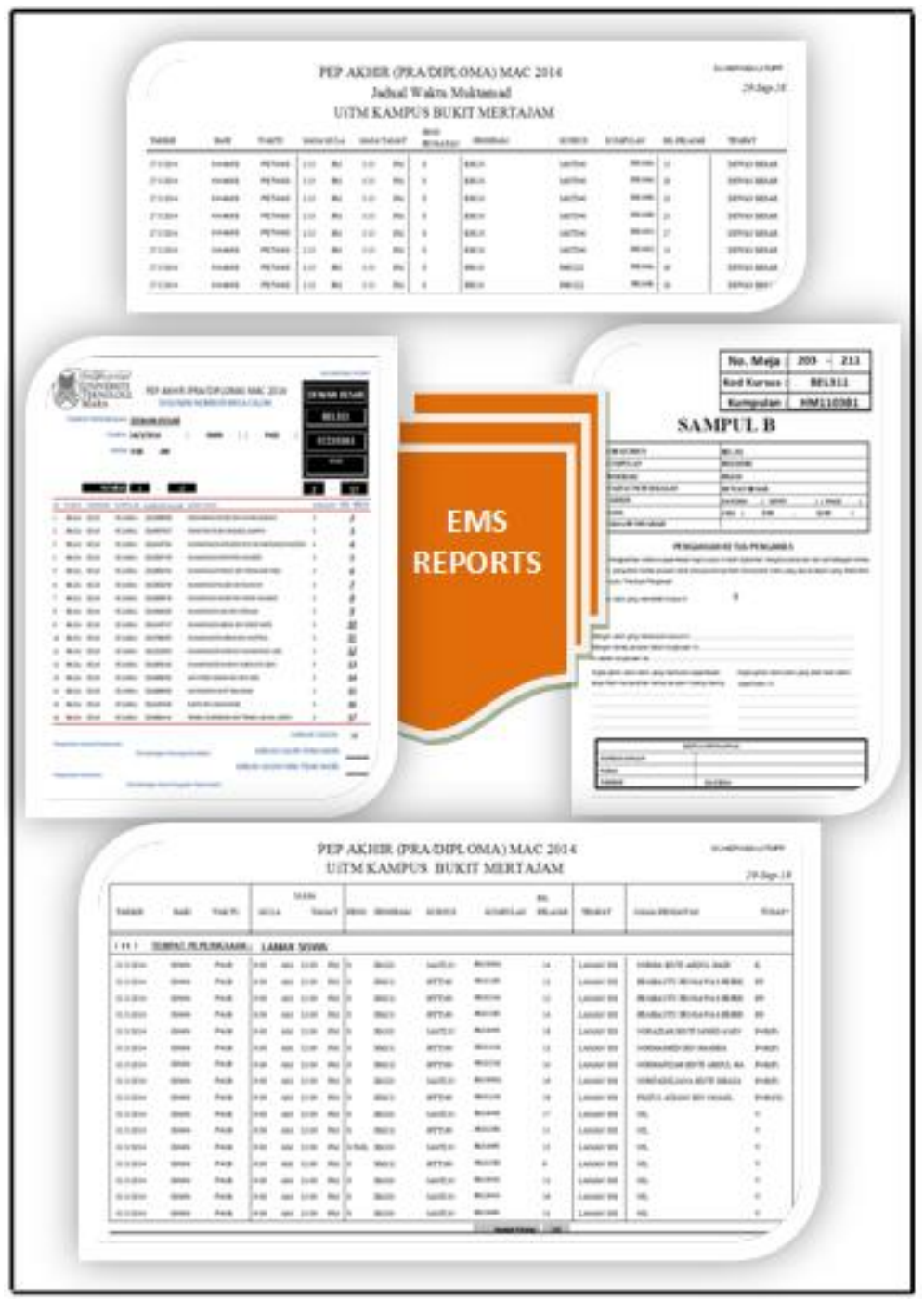

Figure 2: Samples of Reports Generated by EMS Database

Basically the reports are organized accordingly to several phases, starting from the first phase which will be concentrated on examination placement reports. The next phase will be focused on producing reports for seating numbers arrangement. The printing and packaging reports come after the seating numbers arrangement have been verified by the Academic Assistant Registrar. The final phase is generating the invigilation reports and others reports which related to the operational and handling of examination by the respective admin clerks. All reports are integrated in a single database. The following figure shows the list of EMS reports that can be generated from Microsoft Access. 


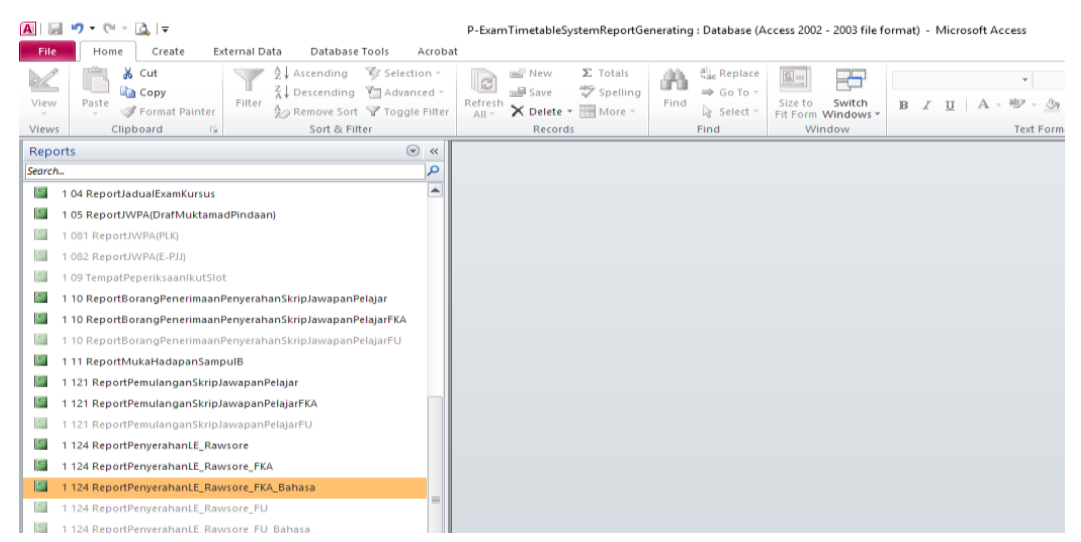

Figure 3: List of EMS Reports in Microsoft Access

\section{EVALUATION PROCEDURE}

This section explains the procedure taken to evaluate the prototype. In this section, the procedure taken in designing questionnaire, collecting data procedure, analyzing the collected data and discussion of the result are presented. The objective of this study is to examine the user acceptance level of the EMS and to prove that the system is effective to improve the efficiency and able to reduce the operational risks. We choose a survey method in this study and; a set of questionnaires is prepared adapted from Technology Acceptance Model (TAM) (Davis, 1985, 1989; Venkatesh \& Davis, 2000).

EMS has been implemented in March 2014 at UiTM Cawangan Pulau Pinang, Permatang Pauh Campus. A survey of user acceptance level among staff is conducted after one year of system implementation. Apart from studying the user acceptance, this survey also measures the quality of service and operation of examination specifically at Permatang Pauh Campus. Scope of the survey is limited to the main campus of UiTM Cawangan Pulau Pinang, excluding the Bertam Campus. The survey focuses towards the new format of examination report, invigilation management and handover process of question paper packs to the chief invigilators.

\section{Questionnaires Design}

The questionnaires design approach follows the same approach that was used in this study (AbuDalbouh, 2013; Alharbi \& Drew, 2014; Wallace \& Sheetz, 2014). As stated by (Wallace \& Sheetz, 2014), the TAM has been successful in helping to evaluate the user acceptance of new technology. There are seven questions need to be answered. The following table is the list of selected questions which are relevant to the scope of the study.

Table 1: List of Questions for the Study

\begin{tabular}{cl}
\hline $\begin{array}{c}\text { Question } \\
\text { number }\end{array}$ & \multicolumn{1}{c}{ Question descriptions } \\
\hline $\mathbf{Q 1}$ & $\begin{array}{l}\text { Overall operational of examination management at UiTM } \\
\text { Cawangan Pulau Pinang is satisfactorily. }\end{array}$ \\
Q2 & $\begin{array}{l}\text { Handling of examination at the venue with high capacity } \\
\text { of students is easy. }\end{array}$ \\
Q3 & $\begin{array}{l}\text { The new format of reports generated by EMS has eased } \\
\text { the invigilation operations. }\end{array}$ \\
Q4 & The seating number arrangement has eased the \\
\hline
\end{tabular}




\begin{tabular}{|c|c|}
\hline & $\begin{array}{l}\text { handling of examination operation at the examination } \\
\text { hall. }\end{array}$ \\
\hline Q5 & $\begin{array}{l}\text { There is no bottle neck at the vault during handover of } \\
\text { question paper packs to the chief invigilators. }\end{array}$ \\
\hline Q6 & $\begin{array}{l}\text { The submission of LE, softcopy of result and students' } \\
\text { books script to Examination Unit has smoothened the } \\
\text { process flow. }\end{array}$ \\
\hline Q7 & I satisfied with the duty of invigilation received. \\
\hline
\end{tabular}

The Likert-scale 1 to 5 is used for the measurement level of users' satisfactions. 1 is representing strongly disagree, 2 is disagree, 3 is representing mildly agree, followed by 4 as agree and finally 5 is strongly agree.

\section{Data Collection}

The survey started since April 2015 examination session for pre/diploma program and ended in June 2017 examination session for degree program. The Examination Unit managed to conduct this survey for 10 consecutive sessions of final examinations from the year 2015 to 2017. The questionnaires have been distributed to all chief invigilators only and the forms were collected immediately after the duty of invigilation was completed. A total of 451 chief invigilators responded the survey.

\section{Result and Finding}

Based on the survey distributed to the invigilators, the researchers found that some of the questions were not answered because it is not relevant to their job scope as chief invigilators. Example, for those proctors invigilated at the small room with capacity less than 40 students, they will ignore question number $(\mathrm{Q} 2)$. The chief invigilators had made assumption that the $\mathrm{Q} 2$ were referring to invigilation that take place at Dewan Besar (capacity $=650$ ), Laman Perdana (capacity $=339$ ), Laman Siswa (capacity $=232$ ), Dewan Delima (capacity $=230$ ) or Dewan Kristal (capacity $=258$ ). The following table shows the summary of analysis for each question by determining the mean and median values.

Table 2: Analysis of Users' Satisfactions or Perceptions Level

\begin{tabular}{cccc}
\hline $\begin{array}{c}\text { Question } \\
\text { Number }\end{array}$ & $\begin{array}{c}\text { Total } \\
\text { respondents }\end{array}$ & $\begin{array}{c}\text { Mean } \\
(\overline{\boldsymbol{x}})\end{array}$ & $\begin{array}{c}\text { Median } \\
(\tilde{\boldsymbol{x}})\end{array}$ \\
\hline Q1 & 451 & 4.3272 & 4 \\
Q2 & 438 & 4.2060 & 4 \\
Q3 & 451 & 4.5337 & 5 \\
Q4 & 451 & 4.7771 & 5 \\
Q5 & 451 & 4.4268 & 4 \\
Q6 & 451 & 4.2716 & 4 \\
Q7 & 451 & 4.3776 & 4 \\
\hline
\end{tabular}

The above table shows that the users' satisfaction level for each question is very encouraging. The mean or average obtained is more than $4.0000(\overline{\mathrm{x}}>4.0000)$. These portray that all respondents agreed and are satisfied with the implementation of EMS. Most of the invigilators are happy with the duty of invigilation assigned to them. According to Ong, Liew, \& Sim (2009) has stated that the Invigilation Information System (IIS) has improved the users' satisfaction especially on duty of invigilation. The invigilators or proctors are given opportunity to inform the day that they can't invigilate. The constraints date or session 
will be set in the system and duty of invigilation prevents those constraint dates. The invigilators are still given a space for invigilation exchange amongst invigilators if their duty of invigilation coincidently clashed with other important task or responsibility. The invigilation duty will be emailed to each invigilator after the EMS generates the schedule and double examined by the examination committee. This process took less than 2 days. Previously it took almost one week to assign properly the invigilation duty to each invigilator. Ozturk, Ozturk, \& Sagir (2010) has mentioned that the invigilation system is seen that the required time for the assignments is dropped from a few days to seconds and reaches optimum results in a few seconds. This has shown that the EMS improves the efficiency of invigilation preparation, equally distributed total invigilation amongst invigilators and reduces the erroneous of invigilators or proctors assignment. Nevertheless, the human touch factors are also considered so that the invigilation schedules received by the proctors are agreeable. Amongst the human touch factors that will be considered are giving flexibility to the proctors who are pregnant, having health issues or Muslim male proctors on Fridays. In consideration of those pregnant proctors, they will be invigilating in a small room and the number of invigilation is reduced. For the case of invigilators who have health issues such as suffering from heart and knee problems, they will be invigilating at the ground level or nearby to examination unit. With respect to the Muslim male obligatory on Friday prayers, we provide more female invigilators on Friday afternoon session so that the male invigilators can perform the Friday prayers without rushing. Others minor human touch factor is the mutual agreement between the examination committee and invigilators. This process of manual adjustment requires less than 2 hours for final verification before the invigilation schedule are distributed to all invigilators.

Respondents were agreed that there is a great improvement of examination operation since the implementation of EMS whereby it automates most of the manual tasks such as the handover of the question paper, the returning of the examination script and submission of restemplate hardcopy and softcopy to Examination Unit. Simulation has been conducted to determine the duration taken for the handover process of question paper packs to the chief invigilator. The time taken was not more than 10 seconds, which is the chief invigilators just need to confirm the particulars of question paper packs received and subsequently signed the form. In the previous method, the chief invigilator must fill in the form and all processes took more than 1 minute. Similarly, the submission of restemplat hardcopy and softcopy are smoother because the lecturers are only required to sign the form with all particulars is already printed and this process took less than 1 minute.

The examination table number system was implemented since EMS is introduced at UiTM Cawangan Pulau Pinang. Before the implementation of EMS, the chief invigilator has to call the students by course group and this took longer time to arrange the students seating arrangement in the examination hall. The chief invigilator even has to repeatedly call the students who arrived late at the examination hall and this required additional time. Consequently, in some cases, the examination did not start or finishes punctually. The examination table number system helps the invigilators on student seating arrangement in the examination hall. The student will refer the seating number arrangement and halls plan at the notice board outside the examination hall and the students find the table as numbered accordingly. The chief invigilator does not need to call repeatedly the students by course group to enter the examination hall. The examination starts and finishes timely. The examination table number system is also implemented at several other campuses and faculties such as UiTM Arau, Bertam, Melaka, Pasir Gudang, Seremban 3 and at Faculty of Computer \& Mathematical Sciences, Shah Alam. The examination table number system is effectively implemented in the bigger examination halls which can accommodate more than 100 students.

Most of the chief invigilators have agreed and responds positively that the new format of forms which generated by EMS has eased the invigilation operation. Previously, the chief invigilator has to manually 
fill-in many forms and this requires almost 30 to 45 minutes for the task to be completed. With EMS, all forms have been auto fill-in and the chief invigilators need to only verify the particulars. This process requires less than 15 minutes. Since the implementation of EMS, the chief invigilators are confident to handle the examination operation at the hall. Previously, the lecturers are reluctant or not confidence to be as chief invigilators because they know that many tasks and responsibility has to be taken into account. They are high risks if any misconduct by any invigilators will affect the credibility of chief invigilator. With EMS, the erroneous in examination operation can be minimized and most of the errors are minor and can be recovered easily.

Overall feedbacks are very encouraging and all chief invigilators having positively agreed that EMS has improved the operation of examination at UiTM Cawangan Pulau Pinang. The positive impact of EMS evaluation is due to the implementation of examination table number system and automated fill in of all examination forms. These two factors are the catalyzer of why EMS successfully implemented in UiTM Cawangan Pulau Pinang. As informal verbal views expressed by one of the invigilator was saying, EMS has solved several major issues especially on the approved students' lists, lack of question paper packaging and operation of invigilation management at the bigger halls.

\section{CONCLUSION}

As mentioned by Bhardwaj \& Singh (2011), Examination Management Systems improves the efficiency and effectiveness of examination administration. Although there is no research being conducted to figure out the cost effective before and after the implementation of EMS, roughly the examination unit has reduced the duty of examination preparation amongst staffs during weekends. This has reduced a lot of the overtime cost amongst their staffs. Indirectly EMS improves the quality time with their family because no interruption of examination responsibility during weekends.

Enhancement of EMS is never stopped and there are a lot of suggestions or positive comments given by the chief invigilators and through benchmarking platforms by UiTM campuses, faculties and local universities. Thus, for the improvement of EMS, the Examination Unit will continuously support the operation of EMS and sustained the good rapport. However, without full supports from the executive level of higher management, the EMS will not be implementable, expandable and sustainable.

\section{REFERENCES}

Abu-Dalbouh, H. M. (2013). A questionnaire approach based on the technology acceptance model for mobile tracking on patient progress applications. Journal of Computer Science, 9(6), 763-770.

Alharbi, S., \& Drew, S. (2014). Using the technology acceptance model in understanding academics' behavioural intention to use learning management systems. International Journal of Advanced Computer Science and Applications (IJACSA), 5(1).

Bhardwaj, M., \& Singh, A. J. (2011). Automated integrated university examination system. Himachal Pradesh University Journal, 1, 156-162. 
Davis, F. D. (1985). A technology acceptance model for empirically testing new end-user information systems: Theory and results. Massachusetts Institute of Technology.

Davis, F. D. (1989). Perceived usefulness, perceived ease of use, and user acceptance of information technology. MIS Quarterly, 319-340.

Griesel, M. A. (1988). Incremental Development and Prototyping in Current Laboratory Software Development Projects: Research Plan. JPL Internal Project Report February 1988.

Lai, W. F. (2012). Research on the Quality Management System of Curriculum Examination in Chinese University. master's thesis, College of Education Central China Normal University.

Ong, M. L., Liew, L. H., \& Sim, J. (2009). Examination invigilation scheduling system in optimising lecturers' preference. In Conference on Scientific \& Social Research (CSSR 08'09).

Ong, M. L., Liew, L. H., \& Sim, J. (2009). Examination invigilation scheduling system in optimising lecturers' preference. In Conference on Scientific \& Social Research (CSSR 08'09).

Ozturk, Z. K., Ozturk, G., \& Sagir, M. (2010). An automated multi-objective invigilator-exam assignment system. International Journal of Information Technology \& Decision Making, 9(02), 223-238.

Quality Manual of UiTM Cawangan Pulau Pinang, I. 9001:2008. (n.d.). Quality Manual of UiTM Cawangan Pulau Pinang, ISO 9001:2008.

UiTM. (2016). Examination Procedures Manual, Academic Assessment Division of UiTM. Springer.

Vasupongayya, S., Noodam, W., \& Kongyong, P. (2013). Developing Examination Management System: Senior Capstone Project, a Case Study. World Academy of Science, Engering and Technology, 7.

Venkatesh, V., \& Davis, F. D. (2000). A theoretical extension of the technology acceptance model: Four longitudinal field studies. Management Science, 46(2), 186-204.

Wallace, L. G., \& Sheetz, S. D. (2014). The adoption of software measures: A technology acceptance model (TAM) perspective. Information \& Management, 51(2), 249-259.

Xu, H., Guo, R., \& Zhou, A. (2013). Design and Implementation of Examination Affairs Management Automation. In 2nd International Conference on Management Science and Industrial Engineering (MSIE 2013). Atlantis Press.

Zhang, T., Liu, M., \& Zang, Z. (2014). Research on the Effective Management of Examination Reform. Open Journal of Social Sciences, 2(10), 105. 